\title{
SURGICAL TREATMENT OF CARDIAC TAMPONADE DEVELOPED IN TWO PATIENTS WITH TERMINAL STAGE LUNG CANCER
}

\author{
Destan Bugra, Ozcan Sedat ${ }^{2}$ \\ ${ }^{1}$ Canakkale Mehmet Akif Ersoy State hospital, Department of cardiovascular surgery, Canakkale, Turkey \\ ${ }^{2}$ Department of cardiovascular surgery, Canakkale university, Canakkale, Turkey
}

Primljen/Received 20. 05. 2020. god.

Abstract: Introduction: Although tamponade due to pericardial effusion that develops in advanced stage lung cancer is rare, it is a life threatening complication. Case report: 59 and 72 years old 2 female patients diagnosed with cardiac tamponade were hospitalized in Cardiology Clinic of Balıkesir State Hospital. Massive pericardial effusion that caused diastolic collapse of right ventricle was detected in their echocardiographies. Inoperable lung cancer was diagnosed as a result of bronchoscopy performed due to pathologies observed in their radiograms. Despite repeated pericardiocentesis, fluid continued to accumulate rapidly. Hence, pericardioperitoneal window was formed through subxifoid route to obtain continuous drainage in both patients. Significant pericardial effusion didn't develop in echocardiographies in the 2nd and the 6th month post-operative follow-ups. Conclusion: Subxiphoid pericardioperitoneal window is a simple, safe and effective surgical procedure. It may be performed in some patients with malignant tamponade.

Key words: Pericardioperitoneal window, lung cancer, pericardial tamponade.

\section{INTRODUCTION}

Chronic exudative pericarditis can cause cardiac tamponade. Although echocardiography guided with pericardiocentesis, especially in effusions related to malignancy, is helpful in some cases, fluids may accumulate again in a short time. In such case, pleuropericardial window can be the choise of treatment. But due to spread of the malignancy this may not be possible in patients with pleurodesis. In this case pericardial-peritoneal shunt is regarded as a solution. Pericardial spread that causes tamponade in lung cancer patients occurs in three ways. These are direct spreads that occur via lymphatic, hematogenous route spread and
Prihvaćen/Accepted 21. 06. 2020. god.

spread from adjacent invasion (1). Tamponade may develop as a result of invasion of malignant cells to pericardium just as it may develop as a result of invasion of lymphatic or blood veins when pericardium is not directly involved (2). Furthermore, pericardial fluid may accumulate after radiotherapy.

\section{Surgical Technique Performed in Patients}

About $4 \mathrm{~cm}$ in lenght, midline incision below xiphoid was performed. Xiphoid was left uncut. Pericardium was opened and accumulated fluid was aspirated. Diaphragm and inferior pericardium was incised forming a window $5-6 \mathrm{~cm}$ in dimensions. The edges of pericardium and diaphragm were sutured using 5/0 Prolene. Also a chest tube was inserted via the first opening to pericardial cavity and it was removed soon as the drainage was diminished.

\section{Case No 1}

A 59 year-old female patient was hospitalized in cardiology clinic with symptoms including dyspnea, tachycardia and wide spread edema in lower extremities. Pericardial and pleural fluid was detected in the echocardiography. Following the examination of sample taken by bronchoscopy performed in Chest Diseases Clinic of our Hospital, squamous cell lung cancer was diagnosed (T4N1M0). Because of rapid fluid accumulation, despite pleural punctures, pleurodesis was performed and positive results were obtained. A month later patient's complaints recurred and she applied to the cardiology clinic of our hospital. Upon detection of pericardial effusion causing diastolic collapse in right ventricle in the echocardiography, clinical picture was adjusted by performing echocardiography guided peri- 
cardiocentesis with diagnosis of cardiac tamponade. Because of the rapid accumulation of pericardial fluid pericardiocentesis became inefficient so surgical drainage was planned. Initially $900 \mathrm{cc}$ hemorraghic fluid was drained following subxiphoid intervention. Because there were severe adhesives, pericardioperitoneal window was formed with a diameter of $5 \mathrm{~cm}$. Histopathological examination of resected pericardium showed the pericardial invasion. Malign cells were observed in the pericardial fluid and there was no reproduction in the culture. During post-operative 2 months follow-up period we didn't see effusion collection.

\section{Case No 2}

A 72 year-old female patient with dyspnea complaint was hospitalized in cardiology clinic. Upon detection of tamponade in echocardiography, patient was relieved with pericardiocentesis. Lung cancer was diagnosed (T4N2M1) following bronchoscopy performed in Chest Diseases Clinic of our hospital due to pathology detected in thorax radiography (Figure 1). Alt-

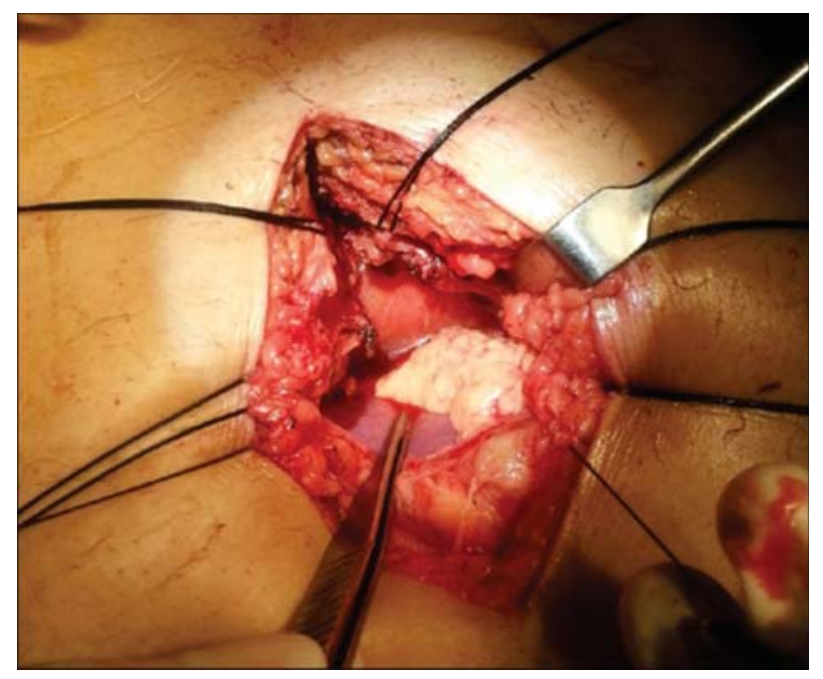

Figure 1. Intraoperative surgical approach

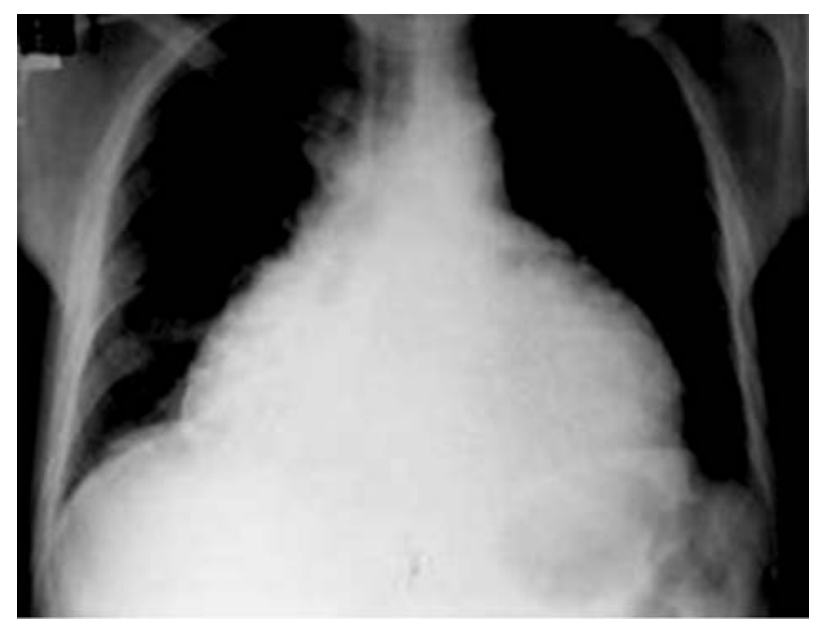

Figure 2. Preoperative chest X-ray hough pericardiocentesis was applied again pericardial effusion was detected and drainage was planned. 1250 cc exudative fluid was drained from pericardium via subxiphoid incision under general anesthesia. Pericarioperitoneal window was created with approximately 6 $\mathrm{cm}$ of diameter (Figure 2). Malign cells were detected in pericardial fluid. There was no reproduction in the culture. The result of pericardium biopsy was adeno cancer. Patient was relieved in post-operative period. Tamponade did not recur in 6 months follow-up period.

\section{DISCUSSION}

Just as malign effusion may ocur as a result of pericardial invasion of malign cells, pericardial fluid may also form by invasion of inflammation, lymphatic and blood veins without any pericardial invasion. This is called paramalign effusion $(1,2)$. Peritoneum cavity has a larger absorption surface than thorax cavity. Rodriguez et al. stated that creation of a pericardioperitoneal window was a simple, safe and efficient procedure and that it can be applied in most cases with malignant or non-infectious benign pericardial effusion and tamponade (3). Some authors stated that it was not clear why fluid drained from negative intrathoracic pressure area to abdominal cavity which has positive pressure (4). They thought that this window would quickly close due to adhesion between liver and omentum. But many researchers stated that this window is efficient and stayed open for a very long time (2). Pericardial window was created with also laparoscopic and thoracoscopic methods in patients with tamponade (5). But if there are advanced adhesivity like in our cases or in case pleurodesis is performed, pericardial window cannot be created laparoscopicly. Although pericardioperitoneal window is considered to be dangerous in malign cases due to risk of peritoneal carcinomatosis, Alotti et al. (3) did not report any development of peritoneal carcinomatosis in any of their cases. Even though peritoneal carcinomatosis develops, this type of patients that have limited life expectancy will be able to spend the last phase of their life without the risk of tamponade. Tamponade can develop in $18 \%$ of the malignancy cases with cardiac involvement (6). Although tamponade is rarely considered as the first symptom for malignity, if a good anamnesis is taken it can be seen that symptoms secondary to malignity such as coughing, dyspnea, malaise, weight loss develops earlier (1). Wang et al. (6) stated that average life of patients with lung cancer following a pericardial drainage was 78 days and only $11,8 \%$ of the patients could live one year. In studies, no relationship between age, gender, tumor type, lymph node metastasis, pleural fluid, dis- 
tant metastasis, symptoms, amount of drained fluid and lifetime are found in the relationship between lung malignancy and tamponade development. Wang et al. (6) reported that cytology of pericardial fluid did not have an effect on the lifetime in non-small cell lung cancer cases that developed tamponade. Video assisted thorascopic surgery (VATS) can only be performed in hemodynamically stable patients because it requires only lung anesthesia (7). When procedure is performed laparoscopically, great caution should be given in the opening of pericardium with cautery. Serious arrhythmia may develop. Intraabdominal pressure should be lowered when pericardium is opened in order to prevent the development of tamponade (7). It is reported that windows with diameters less than $3 \mathrm{~cm}$, will close quickly, approximately in a year due to adhesion in the liver. Thus the need for a window opening over $4 \mathrm{~cm}$ is reported (5). Lymphatic system of heart is the major path in tumoral invasions in heart. Tumor that reaches mediastinal lymph nodes, retrogradely proceeds to lymphatic canals and blocks cardiac lymphatic system. Epicardial lymphatic veins are always attacked early. Due to its poor lymphatic structure, in many cases parietal layer of the pericardium is not attacked by tumoral diffusion in early stages. Even in the early stage where clinical symptoms related to primer tumor does not de- velop and where tumor does not reach a significant size, pericardial effusion can develop due to early invasion of mediastinal lymphnodes (8). Positive results were reported with echocardiography guided percutaneous catheter drainage in cases with tamponade. But in some maligncases repeated effusion has been reported (9). Even though advanced malignity is responsible from the bad prognosis in malign cases, sudden tamponade development especially after the discharge can causedeath.

\section{CONCLUSION}

In conclusion pericardioperitoneal window should be thought as protective factor against sudden deaths that might occur following tamponade in repeated malign pericardial effusions.

Conflict of Interests: The authors declare that there are no conflicts of interest related to this article.

Funding: None

\section{Licensing}

This work is licensed under a Creative Commons Attribution 4.0 International (CC BY 4.0) License.

\title{
Sažetak
}

\section{HIRURŠKO LEČENJE TAMPONADE SRCA RAZVIJENE KOD DVA PACIJENTA SA KARCINOMOM PLUĆA TERMINALNOG STADIJUMA}

\author{
Destan Bugra, ${ }^{1}$ Ozcan Sedat ${ }^{2}$ \\ ${ }^{1}$ Canakkale Mehmet Akif Ersoy State hospital, Department of cardiovascular surgery, Canakkale, Turkey \\ ${ }^{2}$ Department of cardiovascular surgery, Canakkale university, Canakkale, Turkey
}

Uvod: Iako je tamponada usled perikardijalne efuzije koja se razvija kod karcinoma pluća u poodmaklom stadijumu retka, to je komplikacija opasna po život. Prikaz slučaja: Dve pacijentkinje ženskog pola, starosti 59 i 72 godine, hospitalizovane su na Klinici za kardiologiju državne bolnice Bal2kesir zbog dijagnostikovane srčane tamponade. Na njihovim ehokardiogramima je otkrivena masivna perikardijalna efuzija koja je dovela do dijastolnog kolapsa desne komore.

Inoperabilan karcinom pluća je dijagnostikovan bronhoskopijom koja je izvedena zbog patoloških promena viđenih na radiografiji pluća. Uprkos ponovlje-

\section{REFERENCES}

1. Patel N, Rafique AM, Eshaghian S, Mendoza F, Biner $\mathrm{S}$, Cercek B et al. Retrospective comparison of outcomes, diagnostic value and complications of percutaneous prolonged dra- nim perikardiocentezama tečnost se akumulirala rapidno. Zbog toga je formiran perikardioperitonealni prozor subksifoidnim putem da bi se dobila kontinuirana drenaža kod oba pacijenta. Značajan perikardijalni izliv nije se razvio na ehokardiografijama drugog i šestog meseca postoperativnog praćenja. Zaključak: Subksifoidni perikardioperitonealni prozor je jednostavna, sigurna i efektivna hirurška procedura. Može se izvesti kod nekih pacijenata sa malignom tamponadom.

Ključne reči: perikardioperitonealni prozor, karcinom pluća, perikardijalna tamponada. inage versus surgical pericardiotomy of pericardial effusion associated with malignancy. Am J Cardiol. 2013; 112(8): 1235-9.

2. Burazor I, Imazio M, Markel G, Adler Y. Malignant pericardial effusion. Cardiology. 2013; 124(4): 224-32. 
3. Lepska L, Pisiak S, Dudziak M. A case of carcinoid pericardial metastases and massive effusion. Kardiol Pol. 2013; 71(8): 881.

4. Degirmencioglu A, Karakus G, Güvenc TS, Pinhan O, Sipahi I, Akyol A. Echocardiography-Guided or "Sided" Pericardiocentesis. Echocardiography. 2013; 30(9): 997-1000.

5. Fredriksen RT, Cohen LS, Mullins CB. Pericardial windows or pericardiocentesis for pericardial effusions. Am Heart J. 1971; 82(2): 158-62.

6. Wang JL, Hsieh MJ, Lee CH, Chen CC, Hsieh IC, Lin JD et al. Hypothyroid cardiac tamponade: clinical features, electrocardiography, pericardial fluid and management. Am J Med Sci. 2010; 340(4): 276-81.

\section{Correspondence to/Autor za korespondenciju}

Destan Bugra

Canakkale Mehmet Akif Ersoy State hospital

Department of cardiovascular surgery

Canakkale, Turkey

email: bugradestan@yahoo.com
7. Wang LS, Cheng GQ, Chen C, Cao Y. Cardiac tamponade due to fatal pneumopericardium after commercial flight: transportation of a premature infant with chronic lung disease. $\mathrm{J}$ Trop Pediatr. 2013; 59(1): 70-1.

8. Rafique AM, Patel N, Biner S, Eshaghian S, Mendoza F, Cercek B et al. Frequency of recurrence of pericardial tamponade in patients with extended versus nonextended pericardial catheter drainage. Am J Cardiol. 2011; 108(12): 1820-5.

9. Nogueira RB, de Resende RM, Muzzi RA, dos Reis Mesquita L. Alterations in peripheral circulation in dogs with cardiac tamponade. Vet Rec. 2011; 169(11): 280. 